TEMPORAL, Josep: Rondalla meravellosa i filosofia. Una fonamentació antropologicoètica. Premis Ciutat de Manacor, Assaig. Manacor: Món de Llibres, 20I4, 608 p.

\title{
Rondalla meravellosa i filosofia
}

Gemma LluCH CRESPO

Universitat de València

Una anàlisi a la rondalla meravellosa des de noves perspectives pot mostrar cares originals d'un relat polièdric com és la rondalla meravellosa. Aquest gènere que es manté viu en l'actualitat gràcies a l'escola, a les nombroses adaptacions per a infants de totes les edats, a les versions que cada any presenten una nova pel-lícula o un curtmetratge, als anuncis o la vida quotidiana en la qual les protagonistes principals com la Ventafocs, la Bella Dorment o la Blancaneu són habituals per establir símils o comparacions quan es narra la vida d'una nova princesa o d'una cantant d'èxit. Òbviament, un gènere tan ric que s'ha mantingut viu al llarg dels segles, que ha sabut respondre a les necessitats d'un públic amb ganes d'històries, proposa un material inesgotable per als investigadors que el miren des de perspectives múltiples i que, a la manera d'un calidoscopi, apareix a la vista com una figura de simetria radiada de molts colors que varia il-limitadament en transformar-ne la mirada. La fonamentació antropologicoètica que l'investigador Josep Temporal proposa sobre la rondalla meravellosa afegeix un nou color a la figura: el de la filosofia.

La recerca realitzada per Josep Temporal, que ressenyem aquí, conclou que la rondalla meravellosa no versa sobre la realitat humana, sinó sobre la imatge modal de l'home i podria tenir-ne l'origen en la racionalització a què se sotmeté el record dels rituals d'iniciació al món adult. Bàsicament, l'investigador afirma que aquests relats satisfan les expectatives de les preguntes essencials que es formula l'infant. Temporal, a les conclusions, proposa la certesa que un dels ressorts més decisius de la rondalla meravellosa és l'adequació del disseny que el relat té al missatge que transmet. Des de la seua perspectiva, presenta la rondalla meravellosa com un gènere alliçonador, ja que exerceix una funció didacticomoral i recreativa; és a dir, indica una pedagogia antropològica i moral, proposada en termes més pràctics com a alliçonament exemplar de l'heroi i l'heroïna. De fet, manifesta que la presència de la virtut en els personatges de les rondalles és més espontània que premeditada, és una virtut natural. A més, l'acció d'aquest relat s'hi concep com el resultat de la virtut i l'acompliment de la tasca pròpia de cada personatge. En definitiva, les rondalles meravelloses són un reflex dels objectius de les accions amb sentit i del fi últim, constitutius de la realitat humana.

Hem volgut començar la ressenya de la recerca que porta per títol Rondalla meravellosa i filosofia. Una fonamentació antropologicoètica per les conclusions, ja que donen la clau de la importància d'aquesta investigació i situen el lector de ple en el tipus de recerca que desenvolupa aquest llibre.

Al pròleg, Ignasi Roviró Alemany afirma que la visió de la rondalla meravellosa resultant de l'anàlisi és altament pràctica perquè és vista per l'autor com un gènere didàctic i moral que ultrapassa tots els aspectes estètics i literaris que conté. Des de la perspectiva que mostra la recerca, la rondalla és molt més que la narració de les facècies divertides d'uns herois, ja que conté missatges exemplars d'eficàcia 
moral, narrats artísticament i amb la finalitat de fer un ciutadà útil a la societat i feliç. L'heroi és l'exemple a seguir, s'hi presenta com un coratjós, liberal i just; justament, el model que els humans necessitem per orientar-nos davant els problemes i el dubtes.

Roviró finalitza el pròleg afirmant que la rondalla meravellosa té aquesta força transformadora, no pas a causa del seu argument fantàstic ni a causa d'unes estructures perfectament dissenyades a tal fi, sinó que té aquest poder meravellós quan és folklore; quan és paraula modulada artísticament davant una comunitat competent en comunicació, entre els membres de la qual es comparteix un sistema de signes significants; quan es dóna en petit grup i es narra amb la intenció d'assolir uns objectius difícils.

Però quines són les preguntes que han portat l'investigador a les conclusions que hem presentat adés? Bàsicament, en són dues: és possible que les rondalles meravelloses siguin una pura ingenuïtat, desbordants de vacuïtat i de candor enutjós o, si més no, de futileses mancades d'interès racional? És possible que no tinguin res, de contingut antropològic i moral? En iniciar-ne el treball de recerca, aquestes preguntes inicials es transformaren en les següents hipòtesis de treball: és possible encertir el fet que la rondalla meravellosa és un gènere etnopoètic amb contingut antropologicomoral? Si ho és, quina fonamentació té aquest contingut? Així, doncs, si la rondalla meravellosa exerceix una funció didàctica d'ordre moral, si alliçona amb un missatge que versa sobre l'humà i la praxi humana, quina és la clau de la seva eficàcia pedagògica?

Aquestes hipòtesis de treball es treballaren sobre un objecte d'estudi ric, extens i elegit metòdicament. Està format pel corpus de totes les rondalles meravelloses catalanes ja recopilades i establertes en els catàlegs de Josep A. Grimalt, Josep M. Pujol i Carme Oriol i actualment en l'Index of Catalan Folktales i el cercador RondCat. ${ }^{\mathrm{I}}$ En altres paraules, el corpus que analitza Temporal està format per un miler de versions segons l'ordre tipològic internacional d'Antti Aarne, Stith Thompson i Hans-Jörg Uther. ${ }^{2}$ Són versions recopilades en tot el territori de llengua catalana per un total de setanta recopiladors, entre els quals trobem Marià Aguiló i Fuster, Antoni M. Alcover, Rafael Beltran, Pep Coll, Tomàs Escuder, Francesc Gascón, Felix Karlinger, Joan Lluís, Manuel Milà i Fontanals, Maria Dolors Pellicer, Valeri Serra i Boldú, Jordi Raül Verdú o Enric Valor.

En la metodologia d'anàlisi utilitzada per l'autor, les reflexions de lingüistes, antropòlegs, semiòlegs, literats, filòsofs o psicòlegs hi són presents. Òbviament, les aproximacions de Vladimir Propp; la semàntica estructural d'Algirdas Julien Greimas, Claude Bremond, Julia Kristeva, Joseph Courtés o Tzvetan Todorov; la recerca de Roman Jakobson i Petr Bogatyrev o Max Lüthi. Les veus de Roland Bart-

I. GRIMALT, Josep A. (I975): «La catalogació de les rondalles de Mn. Alcover com a introducció a llur estudi». Tesi doctoral. Universitat de Barcelona; OrIOL, Carme; Josep M. PUJOL (2008): Index of Catalan Folktales. Folklore Fellows' Communications 294. Hèlsinki: Suomalainen Tiedeakatemia; RondCat: cercador de la rondalla catalana. Arxiu de Folklore. Departament de Filologia Catalana de la Universitat Rovira i Virgili <http://rondcat.arxiudefolklore.cat> [data de consulta: maig de 20I5].

2. UTHER, Hans-Jörg [ATU] (2004): The Types of International Folktales. A Classification and Bibliography Based on the System of Antti Aarne and Stith Thompson. 3 vols. Folklore Fellows' Communications 284-286. Hèlsinki: Suomalainen Tiedeakatemia. 
hes, Antoni Gramsci, Jean Piaget, Paul Ricoeur o André Jolles dialoguen per interpretar els secrets d'un dels gèneres més conreats i actuals.

La primera part del treball la defineix l'autor com a propedèutica, ja que la conformen dos capítols que aproximen el lector al nucli temàtic de la recerca: l'aproximació etnopoètica, l'antropològica i la psicològica. La segona part és el nucli argumentatiu del treball, i els quatre capítols que la conformen aporten el veritable contingut filosòfic de la recerca i donen resposta a la hipòtesi que planteja l'autor i que hem presentat en els paràgrafs anteriors. Finalment, la tercera part del llibre té una pretensió valorativa i crítica del gènere.

Amb paraules de l'autor, el mapa que vol dibuixar aquesta recerca, i que reflectirà la interpretació de les intencions intangibles de la ment de l'artista, és el de la visió de l'ésser humà que conté la rondalla meravellosa i del missatge moral que aquesta visió hi ha associar. El fet conegut és la dada de la rondalla meravellosa i, en concret, el corpus de rondalles meravelloses del domini etnopoètic de la llengua catalana. La consistència és la manera coherent, sostinguda i inalterable amb què aquesta dada s'ha tractat. La interpretació que s'ofereix és metòdica, perquè s'ha sotmès a la disciplina argumentativa en el sentit amb què ho reclama la ciència i en el sentit que ho exigeix l'escrupolós respecte a la intel-ligència del lector: una exposició racional i fonamentada. Finalment, la interpretació és global, provada i acreditada per l'exhaustiva quantitat d'exemples.

Malgrat que en el títol apareix en primer lloc la paraula rondalla, l'autor el presenta com un treball de filosofia que versa sobre la rondalla meravellosa. ${ }^{3}$ Aquest treball de fonamentació prové d'una tesi doctoral, una tasca de dedicació de quinze anys que va merèixer el premi Ciutat de Manacor d'assaig Antoni M. Alcover el 20I3. Prèviament, Josep Temporal (Olesa de Montserrat, I963) havia publicat Galàxia Propp i, com a coautor, l'obra Ètica i literatura catalana. ${ }^{4}$

Coincidim amb Ignasi Roviró Alemany quan afirma al pròleg que la recerca que presenta Temporal és alhora innovadora i clàssica, ja que, d'una banda, es tracta d'un treball d'aplicació d'una metodologia científica a un objecte d'estudi i, de l'altra, tria com a objecte d'estudi la rondalla meravellosa i la «mirada» és des de postulats filosòfics. El resultat és suggeridor, un repte intel-lectual que provoca una nova mirada sobre un vell relat.

I voldríem concloure aquesta ressenya amb les mateixes paraules que posen el punt final al pròleg de Roviró (p. 27): «La paraula, quan és veritablement paraula en directe — cara a cara—, commou. L'art, si és veritablement art, remou els individus. No els deixa indiferents. L'art i la paraula donada prometen un món diferent. Les rondalles meravelloses, quan es troben sora l'art de la paraula i en petit grup, no estan sotmeses ni a la realitat més immediata ni a una idealitat prefixada d'essències. Projecten un futur prometedor, pel qual val la pena lluitar.»

3. Parlem amb Josep Temporal. Biblioteca Santa Oliva, 25/04/20I4 <https://www.youtube. com/watch?v=9q76xjlxMiE $>$ [data de consulta: maig de 20I5].

4. TEMPORAL, Josep (I998): Galàxia Propp. Aspectes literaris i filosòfics de la rondalla meravellosa. Barcelona: Publicacions de l'Abadia de Montserrat; i MAURI, Margarita; Misericòrdia ANGLÈs; Josep TEMPORAL (2007): Ėtica i literatura catalana. Una aproximació pràctica a conceptes morals a través de la literatura. Barcelona: Universitat de Barcelona. 